\title{
Effect of NaHS on carbonic anhydrase activity of human erythrocyte
}

\author{
Abhijit Bhakta', Maitreyi Bandyopadhyay², Sayantan Dasgupta ${ }^{3}$, Santanu Sen³, Arun Kumar ${ }^{4}$, Utpal Kumar \\ Biswas $^{5}$ \\ ${ }^{1}$ Associate Professor, Department of Anatomy, NRS Medical College, Kolkata, West Bengal, India, ${ }^{2}$ Associate Professor, Deptartment \\ of Microbiology, R G Kar Medical College, Kolkata, West Bengal, India, ${ }^{3}$ Assistant Professor, Deptment of Biochemistry, NRS Med College, \\ Kolkata, West Bengal, India, ${ }^{4}$ Professor, Department of Biochemistry, Shri Shankaracharya Institute of Medical Sciences, Bhilai, Chhattisgarh, \\ India, ${ }^{5}$ Professor, Department of Biochemistry, NRS Med College, Kolkata, West Bengal, India
}

Background: In contrast to its role as poison, hydrogen sulfide $\left(\mathrm{H}_{2} \mathrm{~S}\right)$ is recently considered as a gaso-transmitter which mediates important physiologic functions in humans. Evidence is accumulating to demonstrate that inhibitors of $\mathrm{H}_{2} \mathrm{~S}$ production or therapeutic $\mathrm{H}_{2} \mathrm{~S}$ donor compounds exert significant effects in various experimental models. Carbonic anhydrases (CA) are a group of zinc-containing metalloenzymes that catalyse the reversible hydration of carbon dioxide. CAs activity in erythrocytes (CAI and CAII) has recently been observed to be associated with various pathological conditions especially in diabetes mellitus, hypertension and lipid disorders. Alteration of this enzyme activity has been reported by the effect of advanced glycation end products methylglyoxal and reduced glutathione. Aims and Objectives: $\mathrm{As}_{2} \mathrm{~S}_{\text {, }}$ being a mediator of many physiological functions and synthesized in vivo, may affect functions of many intracellular proteins like carbonic anhydrase, the objective of this study is to find out if there is any change in the carbonic anhydrase activity under the effect of $\mathrm{H}_{2} \mathrm{~S}$ - donor NaHS in dose dependant manner using RBC model in vitro. Materials and Methods: Blood sample was collected from forty (40) numbers of healthy volunteers of 18-40 years of in heparin containing vials and packed cells were prepared immediately by centrifugation The packed erythrocytes were washed three times with normal saline and diluted (1:10) with the normal saline. One $\mathrm{ml}$ each of diluted packed cells was taken in eight test tubes. Serial dilutions of $\mathrm{NaHS}$ ( 1 to $250 \mu \mathrm{Mol} / \mathrm{L}$ ) was added to all the test tubes except for the first test tube where only normal saline was added and incubated at room temperature for one hour. Haemolysates was prepared from the erythrocytes with equal volume of distilled water in each tube and the CA activity was determined in the haemolysates using standardized method.Results: There is significant increase of CA activity in dose dependent manner under the effect of $\mathrm{NaHS}$ and also compared to the activity of hemolysate prepared without NaHS. Conclusions: Our study for the first time demonstrated that the Carbonic Anhydrase activity of erythrocytes is significantly increases by the effect of NaHS and this study reveals some important biological role of $\mathrm{H}_{2} \mathrm{~S}$ and carbonic anhydrase.

Key words: $\mathrm{H}_{2} \mathrm{~S}$, Carbonic anhydrase activity, NaHS, Erythrocytes
Access this article online Website: http://nepjol.info/index.php/AJMS DOI: 10.3126/ajms.v7i3.14047 E-ISSN: 2091-0576 P-ISSN: $2467-9100$

\section{INTRODUCTION}

In contrast to its role as poison, hydrogen sulfide $\left(\mathrm{H}_{2} \mathrm{~S}\right)$ is recently considered as a gaso- transmitter which mediates important physiologic functions in humans. ${ }^{1}$ The physiologic concentrations varies from $1 \mathrm{nmol} / \mathrm{g}$ to 100 $\mathrm{nmol} / \mathrm{g}$ of tissue. ${ }^{2}$ In vitro experiments have validated the generation of $\mathrm{H}_{2} \mathrm{~S}$ from sulfide salts $\left(\mathrm{Na}_{2} \mathrm{~S}\right.$ and $\left.\mathrm{NaSH}\right)$ which inhibits cellular damage and intracellular protein oxidation. ${ }^{3} \mathrm{NaSH}$ is also reported to inhibit lipid peroxides, expression and activity of NADPH oxidase and enhancing hepatic glutathione (GSH) synthesis.

In the central nervous system, $\mathrm{H}_{2} \mathrm{~S}$ functions not only as a neuro-modulator, but also as a neuroprotectant against oxidative stress. $^{4}$ 
Recent reports suggest that $\mathrm{H}_{2} \mathrm{~S}$ play an important role in pathophysiology of many diseases including diabetes mellitus, Alzheimer's disease, hypertension, and cardiac infarction. ${ }^{5-8}$ Pharmacological and molecular biology experiments suggest important roles of $\mathrm{H}_{2} \mathrm{~S}$ as a vasodilator gas in regulation of blood pressure, cardiac response to ischemia/reperfusion injury and inflammation. Furthermore $\mathrm{H}_{2} \mathrm{~S}$ has additional pharmacological targets. It activates $\mathrm{K}_{\text {ATP }}$ and transient receptor potential (TRP) channels, but inhibits big conductance $\mathrm{Ca}^{2+}$ sensitive $\mathrm{K}^{+}$ $(\mathrm{BK}(\mathrm{Ca}))$ channels, $\mathrm{T}$ type $\mathrm{Ca}$ channel and $\mathrm{L}$ type $\mathrm{Ca}$ channel. $\mathrm{H}_{2} \mathrm{~S}$ inhibits the closure of $\mathrm{K}^{+}{ }_{\text {ATP }}$ and release of insulin. Thereby it prevents exhaustion of $\beta$ cells and regulates $\beta$-cell survival. All of the current studies prove that $\mathrm{H}_{2} \mathrm{~S}$ as an endogenous gasotransmitter which draws supreme attention to the research personals in relation to new pathophysiological, biochemical and pharmaceutical aspects worldwide.

On the contrary, carbonic anhydrases (CAs; EC 4.2.1.1.) are a group of zinc-containing metalloenzymes that catalyse the reversible hydration of carbon dioxide. ${ }^{9}$ The great diversity in both cellular distribution and biological functions and the catalytic activity of these isoenzymes is remarkable. Since this enzyme produces and uses protons and bicarbonate ions, carbonic anhydrase plays a key role in the regulation of $\mathrm{pH}$ and fluid balance in different parts of our body. Carbonic anhydrase activity in erythrocytes (CAI and CAII) has recently been explored to link the various pathological sequels in diabetes mellitus, hypertension and lipid disorders. Alteration of this enzyme activity has been reported by the effect of advanced glycation end products, methylglyoxal and reduced glutathione. ${ }^{10-12}$

Recently research proved that CA inhibition represents an effective therapeutic approach towards mitigation of hypertrophic cardiac myocyte growth. ${ }^{13}$ CAs also act on medullary chemoreceptors at two sites. Outside the blood -brain -barrier it acts as plasma buffer, whereas inside the barrier it accelerates $\mathrm{CO}_{2} / \mathrm{pH}$ equilibrium. ${ }^{14}$ The enzyme also has definite role in neuromuscular transmission. ${ }^{15}$ So in recent years, study of carbonic anhydrases, one of the fastest enzymes of biological system, draw attention in medical research not only for its physio-biochemical action, but also for its association with different pathological processes as discussed above. Carbonic anhydrase inhibitors are already in use to as a pharmacological agent in some diseases. The modulation of Carbonic Anhydrase might also be a potential therapeutic strategy for other diseases. Considering the viewpoints and relationship of hydrogen sulfide and carbonic anhydrase, the current study was designed to establish whether any changes in carbonic anhydrase activity occurs with the effect of $\mathrm{H}_{2} \mathrm{~S}$ - donor $\mathrm{NaHS}$ in dose dependant manner using RBC model in vitro.

\section{MATERIAL AND METHODS}

The study was conducted in the department of Biochemistry, NRS Medical College, Kolkata. Forty (40) healthy volunteers, aged ranging $18-40$ years were included in the study after pre-informed consent. The study was pre-approved by the Institutional ethics committee. Five milliliters of blood sample was collected aseptically from the superficial veins of the study subjects in heparin containing vials and packed cells were prepared immediately by centrifugation. The packed erythrocytes were washed three times with normal saline and diluted (1:10) with the normal saline. One $\mathrm{ml}$ each of diluted packed cells was taken in eight test tubes. Serial dilutions of NaHS ( 1 to $250 \mu \mathrm{Mol} / \mathrm{L}$ ) was added to all the test tubes except for the first test tube where only normal saline was added. These were incubated at room temperature for one hour. Haemolysates was prepared from the erythrocytes with equal volume of distilled water in each tube and the CA activity was determined in the haemolysates.

Serum carbonic anhydrase activity was measured using the method used earlier with some modification. ${ }^{16}$ The assay system consisted of $20 \mu$ lof sample (hemolysate) with $800 \mu \mathrm{l}$ of $0.05 \mathrm{M}$ Tris-SO4 buffer (pH 7.4) and $200 \mu \mathrm{l}$ of $3 \mathrm{mM}$ p-nitrophenyl acetate. The change in absorbance at $348 \mathrm{~nm}$ was measured over a period of $3 \mathrm{~min}$, before and after addition of sample using a semi-autoanalyzer (Chem 5 Plus, Transasia). One unit of enzyme activity was expressed as $1 \mu \mathrm{mol}$ of released $\mathrm{p}$-nitrophenol per minute at room temperature.

Statistical analysis was done using Excel for Windows 2007 and SPSS 16 software. The values were expressed as mean \pm standard deviation (SD). $P$-values $<0.05$ was considered statistically significant.

\section{RESULTS}

Our results show that there was a significant increase in carbonic anhydrase (CA) activity under the effect of $\mathrm{NaHS}$ compared to the activity of hemolysate prepared without $\mathrm{NaHS}$ (Table 1). Further there was significant increase of the CA activity by NaHS in dose dependent manner as depicted in Figure 1.

Tables 2 and 3 refers to the ANOVA and ANOVA with Bonferoni tests to determine the test of significance of CA activity compared to the normal hemolysed RBCs and $\mathrm{NaHS}$ treated ones. 
Table 1: Mean \pm SD of carbonic anhydrase (CA) activity $(\mathrm{IU} / \mathrm{ml})$ of hemolysates from RBCs incubated with different concentrations of $\mathrm{NaHS}(\mu \mathrm{Mol} / \mathrm{L})$

\begin{tabular}{|c|c|c|c|c|c|c|c|c|c|}
\hline $\begin{array}{l}\text { Conc. of NaHS } \\
\text { added }(\mu \mathrm{mole} / \mathrm{L})\end{array}$ & 0 & 10 & 25 & 50 & 100 & 150 & 200 & 250 & 300 \\
\hline $\begin{array}{l}\text { CA activity in } \\
\text { IU } / \mathrm{mL}(\text { mean } \pm S D)\end{array}$ & $25.71 \pm 24.88$ & $25.14 \pm 21.51$ & $41.33 \pm 22.48$ & $50.36 \pm 29.51$ & $76.17 \pm 24.48$ & $102.57 \pm 25.46$ & $143.29 \pm 30.99$ & $183.52 \pm 47.69$ & $216.09 \pm 34.56$ \\
\hline
\end{tabular}

\begin{tabular}{lccccc} 
Table 2: Comparisons carbonic anhydrase \\
activity of human erythrocyte under different \\
concentrations of NaHS by ANOVA test \\
All values & $\begin{array}{c}\text { Sum of } \\
\text { squares }\end{array}$ & Df & $\begin{array}{c}\text { Mean } \\
\text { square }\end{array}$ & F & Sig. \\
\hline Aetween groups & 1671108.354 & 8 & 208888.544 & 231.108 & 0.000 \\
Within groups & 333523.476 & 369 & 903.858 & & \\
Total & 2004631.831 & 377 & & & \\
\hline
\end{tabular}

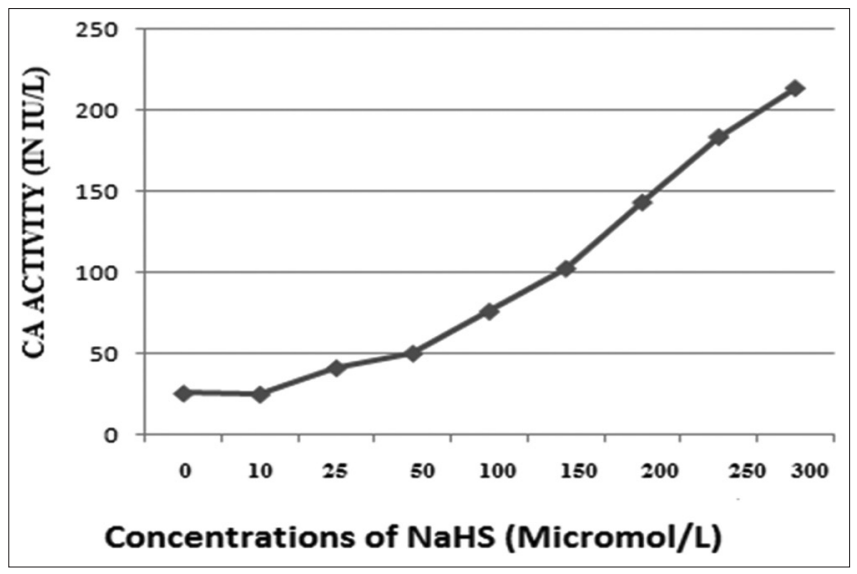

Figure 1: Mean carbonic anhydrase activity of human erythrocyte under different concentrations of NaHS

\section{DISCUSSION}

This present study was designed to observe whether any change in the activity of the erythrocyte carbonic anhydrase occurs under the effect of NaHS. Erythrocytes were incubated with different concentrations $\mathrm{NaHS}$ ( 0 to $300 \mathrm{mMol} / \mathrm{L}$ ) and the activity of CA was determined in the hemolysates.

Evidence from previous study demonstrates that inhibitor of $\mathrm{H}_{2} \mathrm{~S}$ production or therapeutic $\mathrm{H}_{2} \mathrm{~S}$ donor compounds exerts significant effects in various experimental models. ${ }^{17}$ In vitro experiments have shown that $\mathrm{H}_{2} \mathrm{~S}$ generated from sulfide salts $\left(\mathrm{Na}_{2} \mathrm{~S}\right.$ and $\left.\mathrm{NaSH}\right)$ inhibits cellular damage and intracellular protein oxidation. $\mathrm{NaSH}$ is also reported to scavenge lipid peroxides, inhibit the expression and activity of NADPH oxidase, increases hepatic glutathione (GSH) synthesis and decreased lipid peroxidation.

The exuberance over potential clinical applications of natural and synthetic $\mathrm{H}_{2} \mathrm{~S}$ "donating" compounds is understandable and a number of these function-targeted drugs has been developed which shows promising clinical results. However, the concentration of $\mathrm{H}_{2} \mathrm{~S}$ in tissues and blood, and the unknown factors that affect these levels, have not been resolved and therefore it is imperative to address these points in order to distinguish between the physiological, pharmacological and toxicological effects of this molecule. ${ }^{3,18}$

Sodium sulfide $(\mathrm{NaHS})$ and sodium sulfide $\left(\mathrm{Na}_{2} \mathrm{~S}\right)$ have long been used to generate $\mathrm{H}_{2} \mathrm{~S}$. While these are frequently called " $\mathrm{H}_{2} \mathrm{~S}$ donors", and have even been reported to slowly release $\mathrm{H}_{2} \mathrm{~S}$. They are sulfide salts and when placed in water their dissociation and subsequent $\mathrm{H}_{2} \mathrm{~S}$ formation is nearly instantaneous. ${ }^{18}$

The current study reports revealed for the first time, the carbonic anhydrase activity in erythrocytes is significantly increased by increasing concentration of $\mathrm{NaHS}$ in a dose dependent manner (Table I and Figure 1). Tables 2 and 3 refers to the ANOVA with Bonferoni tests to determine the statistical significance of CA activity compared to the normal hemolysed RBCs and NaHS treated ones. In the current study revealed that, the CA activities do not exhibit significant change upto $10 \mu \mathrm{Mol} / \mathrm{L}$ concentrations of $\mathrm{NaHS}$. Significant changes occurred when concentrations of $\mathrm{H}_{2} \mathrm{~S}$ were increased to $100 \mu \mathrm{Mol} / \mathrm{L}$ and above. The overwhelming majority of studies and reviews on the biology of $\mathrm{H}_{2} \mathrm{~S}$ refer to "physiological" concentrations of $20-40 \mu \mathrm{M} \mathrm{H}_{2} \mathrm{~S}$ in blood (with some reports of plasma $\mathrm{H}_{2} \mathrm{~S}$ approaching $300 \mu \mathrm{M}$ ). In turn, $20-300 \mu \mathrm{M} \mathrm{H} \mathrm{H}_{2} \mathrm{~S}$ has been used to validate many "physiological" experiments. However, reports of plasma $\mathrm{H} 2 \mathrm{~S}>1 \mu \mathrm{M}$ have been relatively recent, prior to the year 2000 most reported values were $<1 \mu \mathrm{M}$ and these early studies were largely ignored by those that followed. ${ }^{19}$

In recent years, study of carbonic anhydrases, one of the fastest enzymes of biological system have drawn attention in medical research not only for its physiobiochemical action, but also for its association with different pathological processes as discussed above. Carbonic anhydrase inhibitors are already in use to as a pharmacological agent in some diseases. The modulation of carbonic anhydrase may also be a potential therapeutic strategy for other diseases. CAs activity in erythrocytes (CAI and CAII) has recently been observed to be associated with various pathological conditions especially in diabetes mellitus, hypertension and lipid disorders. The enzyme 


\begin{tabular}{|c|c|c|c|c|c|c|}
\hline \multicolumn{7}{|c|}{ Multiple comparisons } \\
\hline \multicolumn{7}{|c|}{ All values bonferroni } \\
\hline \multirow[t]{2}{*}{ (I) grouping } & \multirow[t]{2}{*}{ (J) grouping } & \multirow{2}{*}{$\begin{array}{c}\text { Mean difference } \\
(I-J)\end{array}$} & \multirow{2}{*}{$\begin{array}{l}\text { Std. } \\
\text { error }\end{array}$} & \multirow[t]{2}{*}{ Sig. } & \multicolumn{2}{|c|}{$95 \%$ confidence interval } \\
\hline & & & & & Lower bound & Upper bound \\
\hline \multirow[t]{8}{*}{0} & 1 & 0.57143 & 6.56055 & 1.000 & -20.5629 & 21.7057 \\
\hline & 2 & -15.61905 & 6.56055 & 0.640 & -36.7534 & 5.5153 \\
\hline & 3 & -24.64286 & 6.56055 & 0.007 & -45.7772 & -3.5085 \\
\hline & 4 & $-50.45238^{*}$ & 6.56055 & 0.000 & -71.5867 & -29.3181 \\
\hline & 5 & $-76.85714^{*}$ & 6.56055 & 0.000 & -97.9915 & -55.7228 \\
\hline & 6 & $-117.57143^{*}$ & 6.56055 & 0.000 & -138.7057 & -96.4371 \\
\hline & 7 & $-157.80952^{*}$ & 6.56055 & 0.000 & -178.9438 & -136.6752 \\
\hline & 8 & $-190.38095^{\star}$ & 6.56055 & 0.000 & -211.5153 & -169.2466 \\
\hline
\end{tabular}

activity is also altered by advanced glycation end products methylglyoxal and reduced glutathione. ${ }^{20}$

$\mathrm{H}_{2} \mathrm{~S}$ donors like $\mathrm{NaHS}$ may effectively increase the activity of the CA enzymes and may be a therapeutic target in the above diseases. Moreover, by changing the activity of these enzyme $\mathrm{H}_{2} \mathrm{~S}$ may cause the alteration of $\mathrm{H}+$ and $\mathrm{HCO}_{3}{ }^{-}$concentrations and may also influence the redox status of the cells. However, large scale study in this direction is needed to understand the proper biological implications and pharmacological potentials of changes in CA activity by NaHS. ${ }^{21-24}$

\section{What this study adds?}

The carbonic anhydrase activity of erythrocytes is significantly increased by increasing concentration of $\mathrm{NaHS}$ in a dose dependent manner.

\section{CONCLUSIONS}

The carbonic anhydrase activity of erythrocytes is significantly increased by increasing concentration of $\mathrm{NaHS}$ and this gives a clue that CA activity in erythrocytes is linked to $\mathrm{H}_{2} \mathrm{~S}$ in its optimum activities. Further large scale study in this direction is needed to understand the pathophysiological implications and pharmacological potentials of changes of NaHS on CA activity.

\section{REFERENCES}

1. Whiteman $M$ and Winyard PG. Hydrogen sulfide and inflammation: the good, the bad, the ugly and the promising. Clin Pharmacol 2011; 4(1):13-32.

2. Whiteman M, Gooding KM, Whatmore JL, Ball Cl, Mawson D, Skinner $\mathrm{K}$, et al. Adiposity is a major determinant of plasma levels of the novel vasodilator hydrogen sulphide. Diabetologia 2010; 53:1722-1726.

3. Wallace JL. Hydrogen Sulphide-releasing anti-inflammatory drugs. Trends Pharmacol Sci 2007;(10):501-505.
4. Abe K and Kimura H. The Possible Role of Hydrogen Sulfide as endogenous neurotransmodulator. The Journal of Neuroscience 1996; 16(3):1066-1071.

5. Szabo C. Roles of hydrogen sulfide in the pathogenesis of diabetes mellitus and its complications. Antioxid Redox Signal 2012; 179(1): 68-80.

6. Sen U, Mishra PK, Tyagi N and Tyagi SC. Homocysteine to Hydrogen Sulfide or Hypertension. Cell Biochem Biophys 2010; 57(2-3): 49-58.

7. Zhu YZ, Wang ZJ, Ho P, Loke YY, Zhu YC, Huang SH, et al. Hydrogen sulfide and its possible roles in myocardial ischemia in experimental rats. J Appl Physiol 2007; 102: 261-268.

8. Yusuf M, Kwong HuatBT, HsuA, Whiteman M, Bhatia M and Moore PK. Streptozotocin-induced diabetes in the rat is associated with enhanced tissue hydrogen sulfide biosynthesis. Biochem Biophys Res Commun 2005; 333:1146-1152.

9. Lewis BHD, Altschule MD and Taylorlood M. Carbonic anhydrase activity in Anaemia, with a note on polycythemia Vera. Blood Journal 1949; 442-454.

10. Demir C, Demir H, Esen R, Atmaca M and Tasdemir E. Erythrocyte Catalase and Carbonic Anhydrase activities in Acute Leukemias. Asia Pacific J Cancer Prev 2010; 11, 247-250.

11. Russell BJ, Loesebrink B and Chernick V.Enhanced Fetal Erytrocyte Carbonic anhydrase Acyivity by Hydrocortisone. Pediatric Research 1976; 10:779-782.

12. Alveraz BV, Johnson DE, Sowah D, Soliman D, Light PE, Xia $\mathrm{Y}$, et al. Carbonic anhydrase inhibition prevents and reverts cardiomyocyte hypertrophy. J Physiol 2007; 579(1): 127-145.

13. Szabó C. Hydrogen Sulphide and its Therapeutic Potential. Nature Reviews 2007; 6: 9-17.

14. Russell BJ, Loesebrink B and Chernick V. Enhanced Fetal Erytrocyte Carbonic anhydrase Acyivity by Hydrocortisone. Pediatric Research 1976; 10:779-782.

15. MA Hanson, PC Nye and RW Torrance. The Location of Carbonic anhydrase in relation to the blood brain barrier at the medullary chemoreceptors of the cat. Physiol Nov 1981 320(1) 113-125.

16. Racker E. In Colowick SP and Kaplan NO (Editors). Methods in Enzymology. Vol.III. New York: Academic Press 1963; pp 283.

17. Caliendo G, Cirino G, Santagada V and Wallace JL. Synthesis and Biological Effects of Hydrogen Sulfide (H2S): Development of H2S-Releasing Drugs as Pharmaceuticals. J Med Chem 2010; 53: 6275-6286. 
18. Wagner F, Asfar P, Calzia E, Radermacher P and Szabo C. Bench-to-bedside review: Hydrogen sulfide-the third gaseous transmitter: applications for critical care. Critical Care 2009; 13:213.

19. Olson KR. The Therapeutic Potential of Hydrogen Sulfide: Separating Hype from Hope. Am J Physiol Regul Integr Comp Physiol 2011; doi:10.1152/ajpregu.00045.2011

20. Biswas UK, Kumar A. Study on the changes of Carbonic Anhydrase activity in Insulin resistance and the Effect of Methylglyoxal. J Pak Med Assoc 2012; 62(5):417-421.

21. Szabo C. Roles of hydrogen sulfide in the pathogenesis of diabetes mellitus and its complications. Antioxid Redox Signal 2012; 1791: 68-80.

22. Kun Qu, Christopher PLH, Halliwell B, Moore PK, Peter T, Wong $\mathrm{H}$, et al. Hydrogen Sulfide Is a Mediator of Cerebral Ischemic Damage. Stroke 2006, 37:889-893.

23. Ling Li,Rose $\mathbf{P}$ and Moore PK. Hydrogen Sulfide and Cell Signaling. Annual Review of Pharmacology and Toxicology 2011; 51:169-187.

24. Zoccali C, Catalano C and Rastelli S. Blood pressure control: hydrogen sulfide, a new gasotransmitter, takes stage. Nephrol Dial Transplant 2009; 24: 1394-1396.

\section{Authors Contribution:}

AB and MB - Preparation, Drafting and Revision of manuscript; SD and SS - Data Acquisition, Data Analysis, Revision of Manuscript; AK and UKB - Concept and design of the study, Manuscript Preparation, Editing and Final Approval.

Source of Support: Nil. Conflict of Interest: None 